\title{
Psychocardiology's Contributions to Comprehensive Cardiovascular Care in Cuba
}

\author{
Teresa Rodríguez-Rodríguez MS PhD, Juan José Navarro-López MD MS, Claudio González-Rodríguez MD MS, \\ Luis F. Herrera-Jiménez PhD, Arelys Falcón-Hernández MD MS, Rolando L. Rivera-López MS, Aleany Nohaya-Alonso MS
}

\begin{abstract}
This paper describes psychocardiology studies conducted from 2002 through 2018 in the Cardiology Department of the Dr Gustavo Aldereguía Lima University General Hospital in Cienfuegos Province, Cuba. Given the strong association between cardiovascular diseases and lifestyle, negative emotions and personality traits, psychology and medicine are equally necessary components of prevention and patient care, indispensable to primary and secondary prevention and to rehabilitation. When its therapeutic principles are appropriately applied, psychology can have a positive impact on the course of the disease and on patients' adaptation to new habits and lifestyles. The psychocardiologist's job is fundamental in achieving conscious participation by patients in their rehabilitation. Theoretical and practical contributions include a gender-based approach, addressing patients' sexual needs, neuropsychological assessment of damage associated with cardiovascular diseases, the particularities of pediatric patient care, family involvement in rehabilitation, and services for families at risk for cardiovascular events due to genetic factors. Results of these studies are included in published methodology for intensive psychological treatment for patients and health care workers.
\end{abstract}

KEYWORDS Psychology, cardiology, cardiac rehabilitation, Cuba

\section{INTRODUCTION}

The importance of risk factors in cardiovascular diseases has been acknowledged by medical science for over 60 years. WHO has called for cooperation and collaboration toward reducing premature mortality from noncommunicable diseases by 2025 , including cardiovascular diseases, which remain the main cause of death and disability worldwide.[1] Preventive activities and lifestyle modifications are needed to reduce the risk, morbidity and mortality of cardiovascular diseases.[2] In Cuba, these diseases have followed an upward trend for the last 10 years and are the leading cause of death.[3]

The key role of psychological factors in the onset and evolution of cardiovascular diseases and their risk factors, including sociopsychological factors, has been recognized for years.[4] In Cuba, psychocardiology has contributed new theoretical and practical approaches based on outcomes of research conducted in 2002-

\section{IMPORTANCE}

The theoretical and practical contributions of psychocardiology to comprehensive care of patients with cardiovascular diseases make a positive impact on their rehabilitation. This article describes those contributions, emphasizing the multidisciplinary approach adopted in a Cuban provincial hospital.
2018 in the Cardiology Department of the Dr Gustavo Aldereguía Lima University General Hospital (HGAL) in the central province of Cienfuegos.[5-8] As a result of these studies, psychocardiologists are incorporated into treatment in phase 1 cardiovascular rehabilitation (during hospitalization) and continue through phase 2 convalescence (generally, two to six months after discharge) and phase 3 (lifelong maintenance).

\section{DEVELOPMENT}

Background Certain personality traits increase the risk of cardiovascular diseases, particularly type A personality, in which hostility is a predictive factor,[9] and type $D$ personality, characterized by depression, social alienation and suppression of negative emotions.[10] Depression accelerates disease progression; induces tachycardia, ventricular arrhythmia and fatal fibrillation; and is associated with functional deterioration and adverse cardiac events.[10] Stress can raise blood pressure and heart rate, and affect other physiological mechanisms and lifestyle. Hemodynamic activation can trigger acute coronary episodes in individuals with atherosclerotic plaque and is associated with recurrence of cardiac events and death. Anxiety diminishes quality of life. Among anxiety disorders, post-traumatic stress is a risk factor for cardiovascular diseases.[10] Socioeconomic factors and poor social support are predictive of adverse clinical outcomes in cardiovascular diseases.[10]

In line with this, in 1998, the Status and Consensus Conference on Psychocardiology noted the importance of behavior and several psychosocial risk factors in the etiology, development, rehabilitation and management of cardiovascular diseases.[11,12] These factors include socioeconomic inequality, emotional stress, exhaustion, anxiety and depression, chronic emotions, type A personality, hostility, and lack of family and social support. Importance was given to preventive treatment (diet, exercise, smoking cessation and introducing medication) to reduce stress. Recommendations included gender studies with emphasis on risk factors in women, behavioral and other psychosocial risks, and the benefits of postmenopausal hormone replacement.[11] These contributions are the foundation of the cardiac rehabilitation guidelines currently in use in many countries.

Psychocardiology emphasizes the high comorbidity between psychiatric disorders and cardiovascular diseases, including psychosocial risk factors in primary prevention, as well as the importance of psychotherapeutic intervention in early stages of the disease, in hospital care and in outpatient cardiac rehabilitation.[13]

As a result of these contributions, a medical subspeciality in psychocardiology was proposed, covering epidemiological, biological and psychosocial factors; clinical disease management; and integration of cardiology, psychology and psychiatry in cardiology research.[14] Despite extensive knowledge about the role of psychological and social variables in cardiovascular diseases, collaboration between medicine and psychology is lacking and 
comprehensive, multidisciplinary approaches in medical practice are rare.

Theoretical contributions Psychological intervention is indispensable in primary and secondary prevention, and rehabilitation. Given the strong association between cardiovascular diseases, negative emotions, personality and lifestyle, disease prevention and treatment require equal provision of clinical and psychological care. Psychology must go hand in hand with prevention activities and clinical procedures throughout cardiovascular patients rehabilitation. When the therapeutic principles of psychocardiology are appropriately applied, they make a favorable impact on the course of the disease and on patients' adaptation to a new lifestyle. Furthermore, psychocardiological care is an important resource for ameliorating negative emotional responses to the invasive procedures needed to treat many patients. Together with physicians, psychocardiologists participate in modifying unhealthy behaviors and also play a fundamental role in preparing families, who provide indispensable patient support and can be promoters of lifestyle changes. In primary prevention, the specialty also plays an important role in identifying hereditary predispositions. The psychocardiologist intervenes in the treatment of neurological damage and its neuropsychological effects, applies a gender-based approach, and addresses sexual issues and their association with coronary conditions throughout the prevention and rehabilitation process. In Cuba, psychocardiology has presented new theoretical arguments in this field.[5-7]

Practical contributions to cardiovascular rehabilitation Theoretical knowledge of these conditions' psychosocial aspects is extensive but seldom applied in clinical care.[12] This section describes practical applications of these principles.

Conscious participation by patients in cardiovascular rehabilitation Psychocardiologist interaction with patients begins in the disease's acute stage and aims to modify behavior following hospital discharge by raising awareness of necessary lifestyle changes. Psychocardiologists help patients understand their condition, as well as the need to modify their lifestyle and control their emotions to improve recovery. This includes providing resources facilitating the behavior modification that is essential for clinical stabilization and success of clinical treatments. These health professionals help patients redesign their behavior by introducing heart-healthy habits as a means to self-care, which will later become selfregulated and conscious daily behaviors. The family-an essential component in rehabilitation-participates in this process as an agent of lifestyle change.[6,7]

Psychological intervention in phase 1 of cardiovascular rehabilitation developed in the Dr Gustavo Aldereguía Lima University General Hospital is termed "intensive psychological treatment in special situations," $[6,7]$ unprecedented in Cuba and undocumented in the scientific literature reviewed from other countries.[12] It initiates tertiary prevention through attitude modification and by helping patients cope with hospitalization, emotional control in crisis situations, and modifying physiological processes exacerbated by such emotional states. It is applied as soon as patients are admitted and continues in a planned, systematic way until discharge, respecting both the disease complexity and patient disposition. $[6,7]$

These results have been applied in other settings for patients with stroke and other cardiovascular or circulatory conditions, as well as for diabetics, pregnant women with chronic conditions, and health workers with chronic conditions or risk factors.

Neuropsychological assessment Patients suffering cerebral hypoperfusion may present cognitive decline associated with cortical pseudolaminar necrosis and hippocampal sclerosis. Traditional risk factors for cardiovascular diseases are also associated with a decline in cognitive function in people with heart disease.[15] Patients whose condition compromised oxygen supply to the brain may present alterations in their ability to plan and anticipate their actions, in processing information, and in mobilizing the resources needed to correctly maintain cortical tone.[7] Damage to cognitive functions interferes with rehabilitation and hinders therapeutic adherence. The psychocardiologist's job is to detect possible cognitive damage during phase 1 and to design therapeutic strategies aimed at cognitive stimulation to be implemented with family participation and extended through phases 2 and 3.[7]

Gender-based approach Implementation of specific genderbased strategies is needed to improve outcomes of cardiovascular therapy.[16] The specificities of prevention and treatment in women has gained importance, and there is growing research on the interactions between psychosocial and biomedical factors in women with heart disease.[17] Some studies look only at traditional risk factors in these conditions in women;[11] others highlight the need to investigate gender differences.[12] Our approach takes into account from the start of therapy[7] the differences between men and women with ischemic heart disease that are associated with personality traits presenting as differences in expression and control of emotion, in fulfillment of productive and reproductive roles, in willingness to actively participate in selfcare,[7] and in vulnerability to health risks.[18]

Addressing altered sexual response Alterations in sexual response are common in people with cardiovascular diseases, due to organic or psychological causes, or the effects of medication.[19] Several authors address the impact of sexual dysfunction on patients' quality of life, and recommend guidance based on lifestyle, physical activity, and the possibility of medication (sildenafil); $[2,19,20]$ however, this assistance is rarely provided. [19] Our psychocardiology care program includes sexual counseling that takes into account subjective factors. It is carried out by means of consensus between the cardiologist and the psychocardiologist at the acute phase, during which a sexological diagnosis is made, which can include drug therapy and counseling for the patient and their spouse or partner. These therapeutic components are also included in outpatient treatment. $[7,8]$

Multidisciplinary approach to cardiovascular rehabilitation Phase 1 cardiovascular rehabilitation requires teamwork involving cardiologists, psychologists, nurses and rehabilitation specialists. Data of psychological interest are recorded in the patient's chart. Nursing staff have been trained in applying emotional control techniques reflected in clinical indications. In the days leading up to hospital discharge, doctors, nurses and psychotherapists participate in group activities with patients and their families to reinforce learned techniques, motivate lifestyle changes and prepare for the return home. Cardiologists have gained an understanding of patients' psychophysiological responses and assist with psychological interventions, particularly in severely ill 
patients. This approach integrates knowledge in designing selfhelp methods and materials for phases 2 and 3.[6,7]

Pediatric psychocardiology Children with congenital heart disease frequently present anxiety, depression, psychological conflicts, low self-esteem, learning difficulties and rejection of lifestyles imposed by the disease as well as medical care. In Cuba, cardiovascular rehabilitation provides psychological resources for coping with and adapting to the particular living conditions the disease implies for children and their families. It supports the process of social integration in phase 3 , which includes education for school-age children.[21]

Psychological care addresses needs of pediatric patients and their families, who have the difficult task of establishing an appropriate lifestyle, detecting psychological changes generated by the disease and notifying specialists responsible for care. A psychological care protocol for school-age pediatric cardiology patients has been created and is being evaluated in Cienfuegos Province to verify its benefits and make necessary adjustments. The protocol's introduction in other Cuban institutions is expected, culminating with a set of nationally standardized guidelines for psychocardiac care of pediatric patients and their families.

\section{CONCLUSIONS}

Despite the importance of psychological interventions in hospitalized heart patients, there are few published studies.[2,12,20,22] The described approach provides a methodology for psychocardiological intervention in acute-phase cardiovascular patients. It contains diagnostic techniques, self-help materials, relaxation methods and other psychotherapeutic techniques for phases 2 and 3 described in the Programs and Methodologies section of the book Psychocardiology in the Health-Disease Process: from Theory to Practice,[7] integrating knowledge from the fields of cardiology and psychology, and which was awarded the 2014 Annual Health Prize by the Ministry of Public Health. In 2019, the supporting studies were also awarded the Annual Health Prize for applied research.

Generalizing these results to all cardiology services in the country requires postgraduate training of cardiologists, psychologists and health policymakers in the comprehensive management of cardiovascular disease. These activities respond to WHO's call to reduce the burden of cardiovascular disease by 2025, and they rely on the political will to guarantee free, universal access to health care in Cuba, from the primary level to specialized cardiology services. -1/

\section{REFERENCES}

1. Pan American Health Organization. Situación de la Salud en las Américas: indicadores básicos 2016 [Internet]. Washington, D.C: Pan American Health Organization; 2016 Oct [cited 2020 May 10]. 20 p. Available at: https://iris.paho.org/ handle/10665.2/31288. Spanish.

2. Grupo de Trabajo de la SEC para la Guía ESC 2019 sobre síndromes coronarios crónicos; Grupo de Revisores Expertos para la Guía ESC 2019 sobre síndromes coronarios crónicos; Comité de Guías ESC. Rev Esp Cardiol [Internet]. 2020 [cited 2020 May 10];73(6):439-44. Available at: https://www.revespcardiol.org/es -pdf-S0300893219306050. Spanish.

3. National Health Statistics and Medical Records Division (CU). Anuario Estadístico de Salud 2019 [Internet]. Havana: Ministry of Public Health (CU); 2020 [cited 2020 May 25]. 193 p. Available at: https://files.sld.cu/bvscuba/files/2020/05/Anua rio-Electr\%c3\%b3nico-Espa\%c3\%b1ol-2019 -ed-2020.pdf. Spanish

4. Mahmood SS, Levy D, Vasan RS, Wang TJ. The Framingham Heart Study and the epidemiology of cardiovascular disease: a historical perspective. Lancet [Internet]. 2014 Mar 15-21 [cited 2020 May 25];383(9921):999-1008. Available at: http://www.sciencedirect.com/science/article/pii/ S0140673613617523

5. Rodríguez Rodríguez T. La Psicocardiología, disciplina indispensable de estos tiempos. MediSur [Internet]. 2010 Jun [cited 2020 May 25];8(3):14. Available at: http://scielo.sld.cu/pdf/ms/v8n3/ v8n3a1156.pdf. Spanish.

6. Rodríguez T. Estrategia de atención psicológica a pacientes con infarto agudo de miocardio en fase hospitalaria [thesis] [Internet]. [Santa Clara] (CU): University of Medical Sciences of Villa Clara; School of Psychology; 2008 [cited 2020 May 25]. 295 p. Available at: http://tesis. sld.cu/index.php?P=FullRecord\&ID=162. Spanish.

7. Rodríguez T, Navarro JJ, González C. Psicocardiología en el proceso salud-enfermedad: de la teoría a la práctica [Internet]. Havana: ECIMED; 2013 [cited 2020 Jun 7]. p. 1-220. Available at: http://articulos.sld.cu/editorhome/2013/12/22/ psicocardiologia-en-el-proceso-salud-enferme dad-de-la-teoria-a-la-practica/. Spanish.

8. Rodríguez Rodríguez T. La atención a la respuesta sexual del paciente con cardiopatía isquémica de debut en fase hospitalaria: consideraciones desde la Psicocardiología. Rev Sexología [Internet]. 2020 Jun [cited 2020 Jun 19];9(1):34-7. Available at: https://www.researchgate.net/publi cation/343452325_La_atencion_a_la_respuesta sexual del paciente con cardiopatia isquemica_de_debut_en_fase_hospitalaria_Con sideraciones_desde_la_Psicocardiologia. Spanish.

9. Myrtek M. Meta-analyses of prospective studies on coronary heart disease, type A personality, and hostility. Int J Cardiol [Internet]. $2001 \mathrm{Jul}$ [cited 2020 Jun 19];79(2-3):245-51. Available at: https://linkinghub.elsevier.com/retrieve/pii/ S0167527301004417

10. Smith PJ, Blumenthal JA. Aspectos psiquiátricos y conductuales de la enfermedad cardiovascular: epidemiología, mecanismos y tratamiento. Rev Esp Cardiol [Internet]. 2011 Oct [cited 2020 Jun 22];64(10):924-33. Available at: https:// www.sciencedirect.com/science/article/abs/pii/ S030089321100594X. Spanish.

11. Canadian Cardiovascular Society 1998 Consensus Conference on the Prevention of Cardiovascular Disease: The Role of Cardiovascular Specialist [Internet]. Ottawa: Canadian Cardiovascular Society; 1998 [cited 2020 Jun 19]. 331 p. Available at: https://ccs.ca/app/uploads/2020/12/ Prev_CC_1998.pdf

12. Jordan J, Bardé B, Zeiher AM, editors. Contributions toward evidence-based psychocardiology: a systematic review of the literature [Internet]. Washington, D.C.: American Psychological Association; 2007 [cited 2020 Jun 22]. 373 p. Available at: https://psycnet.apa.org/ record/2006-13513-000

13. Laham M. Psicocardiología: su importancia en la prevención y la rehabilitación coronaria. Rev Suma Psicolog [Internet]. 2008 Mar 1 [cited 2020 Jun 21];15(1). Available at: https://www.redalyc .org/pdf/1342/134212604006.pdf. Spanish.

14. Byrne D, Alvarenga E. Psychogenesis and Heart Disease Now: The Thinking Heart in Action.
In: Alvarenga M, Byrne D, editors. Handbook of Psychocardiology [Internet]. Singapore: Springer Nature Singapore Pte Ltd; 2016 [cited 2020 Jun 26]. p. 3-12. Available at: https:// link.springer.com/referencework/10.1007\% 2F978-981-4560-53-5

15. Sociedad Andaluza de Neurología. Recomendaciones para el manejo del deterioro cognitivo [Internet]. Sevilla: Editorial Fundación Sociedad Andaluza de Neurología; 2019 [cited 2020 Jun 26]. p. 39-43, 58-60. Available at: http://www.saneurologia.org/ wp-content/uploads/2019/10/LIBRO-DETERIORO -COGNITIVO-DEF.pdf. Spanish.

16. Aggarwal NR, Patel HN, Mehta LS, Sanghani RM, Lundberg GP, Lewis SJ, et al. Differences in ischemic heart disease. Advances, obstacles, and next steps. Circ Cardiovasc Qual Outcomes [Internet]. 2018 Feb [cited 2020 Jun 26];11(2):e004437. Available at: https://www.ahajournals.org/doi/10.1161/ CIRCOUTCOMES.117.004437?url ver $=$ Z39.88 $-2003 \& r f r \_i d=o r i: r i d$ :crossref.org\&rfr_dat $=c r$ pub\%20\%200pubmed

17. Espnes GA, Nguyen C, Byrne D. Gender Differences in Psychological Risk Factors for Development of Heart Disease. In: Alvarenga M, Byrne D, editors. Handbook of Psychocardiology [Internet]. Singapore: Springer Nature Singapore Pte Ltd; 2016 [cited 2020 Jun 24]. Available at: https://link.springer.com/referencework/10.1007 \%2F978-981-4560-53-5

18. World Health Organization [Internet]. Geneva: World Health Organization; c2020. Centro de prensa. Notas descriptivas. Salud de la mujer; 2018 Sep 25 [cited 2020 Jul 2]; [about 7 p.]. Available at: https://www.who.int/es/news-room/ fact-sheets/detail/women-s-health. Spanish.

19. Levine GN, Steinke EE, Bakaeen FG, Bozkurt B, Cheitlin, MD, Conti JB, et al. Sexual activity and cardiovascular disease: a scientific statement from the American Heart Association. Circulation [Internet]. 2012 Feb 28 [cited 2020 Jul 2]; 125(8):1058-72. Available at: https://www.ahajournals.org/doi/10.1161/ CIR.0b013e3182447787?url_ver $=$ Z39.88 $-2003 \&$ rfr_id=ori:rid:crossref.org\&rfr_dat $=c r$ pub\%20\%200pubmed 
20. López-Jiménez $F$, Pérez-Terzic $C$, Zeballos PC, Anchique CV, Burdiat G, González K, et al. Consenso de Rehabilitación Cardiovascular y Prevención Secundaria de las Sociedades Interamericana y Sudamericana de Cardiología. Rev Urug Cardiol [Internet]. 2013 [cited 2020 Jul 2];28:189-224. Available at: https://g-se.com/uploads/blog_adjuntos/rcv28n2 consenso rehabilitacion 2.pdf. Spanish.

21. Carballés JF. García. Evaluación del programa cubano de rehabilitación cardiaca del niño durante los años 1992 a 2010 [thesis] [Internet]. [Havana]: University of Medical Sciences of Havana; 2012 [cited 2020 Jul 2]. 163 p. Available at: http://tesis.sld.cu/FileStorage/000120-2F3A -Jes\%C3\%BAs_Francisco_Carball\%C3\%A9s Garc\%C3\%ADā.pdf. Spanish.

22. Una M. In-Hospital Management of Psychological Responses to Acute Cardiac Events. In: Alvarenga $M$, Byrne $D$, editors. Handbook of Psychocardiology [Internet]. Singapore: Springer Nature Singapore Pte Ltd; 2016 [cited 2020 Jul 2]. Available at: https://link.springer.com/referen cework/10.1007\%2F978-981-4560-53-5

\section{THE AUTHORS}

Teresa Rodríguez-Rodríguez (Corresponding author: teresarr559@gmail.com), psychologist with both a master's degree and a doctorate in the field. Head of the Behavioral Medicine Group in Cuba. Full professor and senior researcher, Dr Gustavo Aldereguía Lima University General Hospital (HGAL), Cienfuegos, Cuba. https:// orcid.org/0000-0003-3114-4624

Juan José Navarro-López, cardiologist with a master's degree in emergency medicine. Associate professor, HGAL, Cienfuegos, Cuba. https://orcid.org/0000-0002-9774-959X

Claudio González-Rodríguez, cardiologist with a master's degree in emergency medicine. Associate professor, HGAL, Cienfuegos, Cuba. https://orcid.org/0000-0003-3774-7258

Luis F Herrera-Jiménez, psychologist with a $\mathrm{PhD}$ in the field. Full professor, Marta Abreu University, Santa Clara, Villa Clara, Cuba. https:// orcid.org/0000-0002-2135-2107

Arelys Falcón-Hernández, physician with dual specialties in family medicine and intensive care, and a master's degree in emergency medicine. Associate researcher, associate professor and rector, Medical University of Cienfuegos, Cuba. https://orcid.org/000-0002-4578-5505

Rolando Lázaro Rivera-López, psychologist with a master's degree in health psychology. HGAL, Cienfuegos, Cuba https://orcid. org/0000-0001-9471-1724

Aleany Nohaya-Alonso, psychologist with a master's degree in health psychology. Paquito González Cueto University Pediatric Hospital. Cienfuegos, Cuba. https://orcid.org/0000-0002 $-3424-0366$

Submitted: August 5, 2020

Accepted for publication: January 8, 2021

Disclosures: None 